\title{
Covid-19 Pandemi Döneminde Otomobil Markalarının Reklam Stratejilerinin Yerelleştirme Kapsamında Değerlendirilmesi
}

\author{
Evaluation of the Advertising Strategies of Automobile Companies within the Scope \\ of Localization During the Covid-19 Pandemic
}

Araştırma/Research

\section{Nurel CENGiZ}

Arş.Gör. Dr., Hacettepe Üniversitesi, Mütercim-Tercümanlık Bölümü, nurelyigit@gmail.com.tr, ORCID ID: orcid.org/ 0000-0003-3362-2204

\begin{abstract}
ÖZET
Reklamların amacı en genel tanımıyla bir ürünü belirli bir kitleye tanıtmak, sevdirmek ve satın alınmasını sağlamaktır. Her toplum farklı bir kültürel kimliğe sahiptir. Farklı değerlere, önceliklere ve en önemlisi farklı dillere sahip toplumların sınırsız muadili bulunan belirli bir ürünü tercih etmesini sağlamak için firmalar reklam kampanyaları aracılığı ile birbirleriyle yarışmaktadırlar. Sınırların ortadan kalktığı ve ekonominin aksamadan faaliyetlerini sürdürmesinin hedeflendiği küresel yeni dünya düzeninde, dünyanın büyük bir köye dönüşeceği ve farklılıkların ortadan kalkacağı ütopyası gerçekçi bir yaklaşım olmaktan uzaklaşarak toplumların kendi kültürel kimliklerini sürdürmeye ve korumaya daha da önem vermeye başladıkları gözlemlenmektedir. Farklı pazarlardaki hedef kitlenin kültürel değerlerini, dil, din, aile yapısı gibi unsurların çözümlenmesi ve elde edilen bulgular ışığında o kitleye ürünü sevdirecek ve satın almaya teşvik edecek, dilsel dünyalarında olumlu bir imaj yaratacak iletişim stratejisinin belirlenmesi küresel firmaların ürünlerinin reklamlarının amacına ulaşması açısından büyük öneme sahiptir. Bu bağlamda global firmalar reklam stratejilerinde daha kültür odaklı yaklaşımlar tercih etmek zorunda kalmaktadırlar. Covid-19 Pandemisi ise dünyada tüm kuralları bir anda alt üst eden bir olgu olarak kendini göstermiştir. Tüm dünyanın bir anda eş zamanlı olarak yavaşladığı, üretimlerin aksadığı ve insanların ihtiyaçlarının ve önceliklerinin değiştiği, sokaklar boşalırken evlerin dolduğu global bir sorun olarak tüm dünyayı etkisi altına almıştır. Reklam firmaları da bu dönemde stratejilerini yeni ihtiyaçlar bağlamında gözden geçirmişlerdir. Mobil olmayı amaçlayan otomobil reklamları acaba pandemi döneminde nasıl bir strateji izlemiştir? Bu çalışmada, tüm dünyayı
\end{abstract}


meşgul eden ve ortak bir paydada buluşturan Covid-19 Pandemisi döneminde, otomobil reklamları üzerinden Türk ve Alman pazarları için hazırlanan reklam stratejileri incelenecektir. Reklamların kültürel çözümlemeleri yapılacak, çeviri stratejileri incelenecek ve reklam anlayışı olarak global ve glokal arasında nasıl bir tercih yapıldığı saptanacaktır.

Anahtar Sözcükler: Global Reklam, Glokal Reklam, Yerelleştirme, Kültür, Reklam Çevirisi

\begin{abstract}
The objective of advertisements is to ensure that a specific audience becomes aware of a product, welcomes it and purchases it. Every society has a distinct identity. The companies compete with each other to enable audiences with different values, priorities and languages to prefer a product which is manufactured under numerous brands. In the new global order where the boundaries are dismantled and the economy is sought to operate flawlessly, the utopia that the world will turn into a global village and that the differences will disappear moves away from the reality itself; hence it is observed that different societies will protect and maintain their own cultural identities. In light of the analysis of the cultural values, religious, linguistic and family elements of the target audience in specific markets, it is significant to identify a fruitful communication strategy which would create a positive image in the linguistic worlds of the different audiences in order to ensure that the global companies reach their aims through advertisements that encourage people to purchase their products. Within this context, the global companies need to prefer a much more culture-oriented approach to advertising strategies. The Covid-19 Pandemic turns into a phenomenon that dismantles all the rules in the world. The pandemic is a global problem that slows down the people, challenges the production processes and alters the needs and priorities of the human beings who have gone through an experience with empty streets and populated home environments. Therefore, the advertisement companies have revised their strategies in line with the changing needs. The question here is this: what kind of strategies are pursued within the context of the automobile advertisements that seek to be mobile. This study seeks to explore the advertising strategies that target the Turkish and German automobile markets within the atmosphere of the Covid-19 Pandemic that has created more or less similar challenges for the entire world. The study will conduct a cultural analysis by reviewing the translational strategies and identify what kind of a choice has been made between the global and glocal advertising approaches.
\end{abstract}

Keywords: global advertising, glocal advertising, localization, culture, the translation of advertisements

\title{
1. Giriş
}

\subsection{Reklam, Global ve Glokal Reklam}

Reklam, insanları gönüllü olarak belli bir davranışta bulunmaya ikna etmek, belirli bir düşünceye yöneltmek, dikkatlerini bir ürüne hizmete, fikir ve kuruluşa çekmeye çalışmak, onunla ilgili bilgi vermek, ona ilişkin görüş ve tutumlarını değiştirmelerini veya belirli bir görüşü ya da tutumu benimsemelerini sağlamak amacıyla oluşturulan; iletişim araçlarından yer ya da süre satın almak yoluyla sergilenen ya da başka biçimlerde 
çoğaltılıp dağıtılan ve bir ücret karşılığı oluşturulduğu belli olan, diğer bir deyimle parasal destek sağlayan kişi ya da kuruluşların kimliğinin açık olduğu duyurularıdır (Gülsoy, 1999, s. 9). Belirli bir ücret karşılığı tüketicilere ürünlerini tanıtarak maddi kazanç elde etmeye çalışan firmalar, reklam kampanyaları için çok büyük bütçeler ayırmak zorunda kalmaktadırlar. Daha fazla kazanmak için yapılan reklam harcamalarının firmanın çıkarları doğrultusunda etkili ve başarılı olmak zorundadırlar.

Reklamın Dili kitabında Batı'nın da ifade ettiği gibi, reklamlar oluşturdukları mesajlarla tanıtımını yaptıkları ürün ya da hizmetle potansiyel tüketicisi arasında bağ kurmayı amaçlar ve reklamlarda anlam üretimi, toplumda önceden var olan kodlardan hareketle işlem görür. Satış amacıyla işlevsel birer iletişim biçimi olan reklamlarda tüketiciyi doğrudan hedefleyen, onları çözümleyen ve isteklerine cevap verebilen reklamlar amaçlanan etkiye ulaşabilirler. Potansiyel tüketicilerine anlamlandırabildikleri kodlar ile anlamlandırabildikleri mesajlar göndermeleri gereklidir (2013, s. 11). Tüketicinin bir mesajı anlamlandırabilmesi ise ancak kendi toplumunun kültür kodları aracılığı ile mümkündür.

$\mathrm{Bu}$ noktada global ve glokal reklam kavramlarını da biraz açıklamamız gerekmektedir. Global reklam iki biçimde tanımlanmaktadır: Her ulusal pazarda yerel dile çevrilerek ya da kimi zaman orijinal dilinde bırakılarak, biçimi değiştirilmeksizin yayınlanan reklamlar ve yayınlandığı tüm pazarlarda aynı reklam fikri doğrultusunda oluşturulmuş, ancak her pazara özgü yerel bir öykü içinde işlenmiş, yerel oyuncularla çekilmiş reklamlardır (Gülsoy, 1999, s. 223). Hangi kampanyanın yürütüleceği ilgili kültürün kodlarının çözümlenmesi sonucu tespit edilebilir.

Global reklamcılığın avantajları ve dezavantajları küreselleşme olgusunun dünya üzerinde etkili olmaya başladığı 80'li yıllardan itibaren çokça tartışılmıştır. Levitt 1983 yılında kaleme aldığı makalesinde küresel reklamların lehine argümanlar sunmuştur ve dünya pazarlarının giderek homojenleşeceğini ve dünyanın dört bir yanındaki tüketicilerin hem ihtiyaçlarının hem de umutlarının, endişelerinin, tutum ve davranışlarının giderek daha fazla benzer hale geleceğini savunmuştur. Savını desteklemek amacıyla Coca-Cola, Pepsi, Sony, Rolex, Mercedes gibi markaların tüm pazarlarda aynı reklam kampanyası ile elde ettikleri başarıyı kanıt olarak sunmuştur. Ancak söz konusu markalar tüm dünyada tanınan ve itibarı yüksek markalardır ve farklı toplumlardaki tüketicileri, yaşadıkları toplumun kültürüne rağmen daha homojen bir kitledir. Örneğin, Pepsi reklamında ünlü bir pop müzik sanatçısının başrolde olan ve hedef kitle tarafından beğenilen pop müziğin reklamda yer alması, haz ve keyif odaklı olan ve 10-25 yaş aralığındaki hedef kitle tarafından tüm kültürlerde kabul görecektir. Öte yandan global reklam fikrine karşı çıkan görüşler özellikle uluslararası kampanyaların ilgili pazarlara veya kültürlere göre uyarlanması fikrini savunmuşlardır ve global reklam fikrinin başarısız olduğu örnekler ile savlarını desteklemişlerdir.

Globalleşme kavramının popülerleşmesine önemli katkıları olan Amerikalı yazar John Naisbitt ve ünlü pazarlama profesörü Philip Kotler farklı toplumların tüketim alışkanlıklarının birbirine benzeme ve homojenleşme eğiliminin yanı sıra farklılaşma ve bireyselleşmeye yönelik güçlü bir eğilim sergilediğini de gözlemlediklerini belirtmişlerdir. (Cahen, 2003) Naisbitt, insanların yaşam tarzları ne kadar homojen olursa, o ölçüde dil, 
Covid-19 Pandemi Döneminde Otomobil Markalarının Reklam Stratejilerinin Yerelleştirme Kapsamında Değerlendirilmesi

din, sanat ve edebiyat gibi tanıdık değerlere o kadar daha tutunduklarını vurgulamıştır (Kloss, 2003, s. 363).

"Globalleşme" (Globalization) ve "Yerelleşme" (Localization) kavramlarından türeyerek ortaya çıkan son zamanların moda kavramı "glokal" yabancı şirketlerin "Küresel düşün, yerel hareket et" (Think global act local) anlayışıyla yerel pazarlara uygun pazarlama stratejilerin geliştirmesini ifade eder. Bu tartışmalardan onlarca yıl sonra küresel firmaların reklam stratejilerine baktığımızda global reklam anlayışından uzaklaşarak glokal reklam kampanyalarına yönelmeleri global reklam fikrine karşı çıkanların haklı çıktığını göstermektedir.

Glokal reklamlar ise, global markaların sadece ilgili hedef pazar için hazırladıkları ve ülkenin kültürüne özgü motiflerin, özelliklerin, değerlerin, hedef ve beklentilerin o kültürün kodları vasıtasıyla yeniden üretilmesidir. Bu sayede reklamı yapılan ürün hedef kitle tarafından kendi değerlerine daha uygun olarak algılanır ve tüketimi tercih edilebilir. Global markaların pazar ve müşteri odaklı bir yaklaşımla belli ülkeler için hazırladıkları ve o ülkeye özgü dil kullanımının, semboller, değerler, normlar ve kültürel boyutların dikkate alınarak hazırlandığı reklam kampanyaları olarak da ifade edilebilir. Günümüzde Coca Cola, Pepsi, McDonald's ve diğer birçok küresel marka her pazara uygun reklam stratejisi benimsemektedir.

\section{Kapsam ve Amaç}

Bu çalışmanın amacı, ünlü markaların tüm dünyayı etkisi altına alan global bir problem karşısında tüketiciyi ikna etme çabası güden ve birer kültürlerarası iletişim aracı olan reklamlarda hedef kitleye global bir söylemle mi yoksa yerel değerlere vurgu yaparak kültür odaklı bir yaklaşımla mı seslendiklerini ortaya koymaktır. Bu çalışmada reklamın alışagelmişin dışında da işlevlerinin olması açısından kullanılan söylem ve tercih edilen strateji önem arz etmektedir. Amacı bir ürünü satmak olan bir eylemin, herkesin evlerinde kalmaya teşvik edildiği, mobil olmaya alışık olan modern insanın uzun süre evinde kaldığı, sokakların, oto yolların boş kaldığı ve gerek üretimin gerekse tüketimin kısıtlandığı bir süreçte tüketicilere kendini nasıl bir söylemle hatırlattığı reklamcılık tarihinde kendine özel bir yer edinecektir.

Bu bağlamda, 2019 yılının Aralık ayında Çin'de ortaya çıkan ve 2020 yılında tüm dünyayı etkisi altına alan Covid-19 Pandemisi döneminde Audi, BMW, Mercedes-Benz ve Volkswagen olmak üzere, Alman otomobil markalarının Almanya ve Türkiye'de gösterilen reklamları incelenecek ve aynı markaların iki yerel pazar için tercih ettiği reklam ve çeviri stratejileri tartışılacaktır. Ünlü markaların bu süreçte reklam metinlerinin çevrilmesini mi yoksa kültürel olarak uyarlanması yöntemini mi tercih ettikleri irdelenecek ve öncelikle global mi yoksa glokal reklam kampanyaları mı yürüttükleri ortaya konacaktır. Bu sınıflandırma yapıldıktan sonra her iki strateji dilsel, göstergebilimsel ve kültürel ölçütler kapsamında incelenecektir. Çeviri yöntemini tercih eden markaların hangi çeviri yöntemlerini kullandıkları analiz edilecek, yerelleştirme yöntemini tercih eden markaların reklamları her iki ülkenin kültür kodları kapsamında incelenecek ve hangi kodlara vurgu yapıldığı ortaya konmaya çalışılacaktır. Bu kapsamda 
belirtilen markaların 2020 yılında belirsizliklerle dolu pandemi döneminde Almanya ve Türkiye'de televizyon kanallarında yayınlanan veya gerek yerel gerek merkezi Youtube kanalları veya Twitter hesapları üzerinden paylaşılan pandemi içerikli iletileri değerlendirme kapsamına alınmıştır.

\section{Kuramsal Çerçeve}

Seçilen reklamlar öncelikle gramatikal olan ve gramatikal olmayan analiz birimlerince ele alınacaktır. Batı (2013), Reklamın Dili kitabında günümüzde reklamların yaygın ve evrensel iletişim kanallarının en önemlilerinden biri olduğunu ve reklamın bir iletişim biçimi olmasının yanında, istenilen etkiyi yaratmak için iletişim biçimlerinin kullanılmasının bir yolu olduğunu vurgular (s. 6). Seçilen reklamlarda kullanılan iletişim biçimlerinin tespiti için öncelikle gramatikal olan değerlendirme ölçütleri kullanılacaktır. Bu ölçüt ile reklamlarda kullanılan dil, düz anlam, yan anlam, retorik, söz sanatları ve çeviri stratejileri, seçilen kelimeler, cümle ve paragraf, birer sembol değeri taşıyan kilit sözcüklerin tespiti ve ana fikir ele alınırken gramatikal olmayan ölçütlere göre de tüm materyal, yani reklamın tamamı bir senaryo olarak ele alınacak, karakterlerin, maddi varlıkların, değer, sembol, ritüel ve kültürel kodların çözümlemesi yapılacaktır.

Hofstede, kültürü soğan modeli ile de açıklamaya çalışır. Soğan modeli kültürlerin farklılıklarının nasıl düzenlenebileceğini görselleştirmeye yarar ve kültürün uygulamalarını ayrıntılı bir şekilde kavramamızı sağlar. Soğanın iç kısımlarına gittikçe kavramlar gözlemciler için daha belirsiz ve daha az gözle görülebilir hale gelir. Soğanın dış kabuğu her biri başlı başına farklı anlamlara gelen kelimeler, resimler, giyinme alışkanlıkları, saç-sakal şekilleri, ses tonu, jest mimik, beden dili gibi gözle görülür sembollere tekabül eder. Bunlar bir kültürde ilk göze çarpan somut olgulardır. Birinci katmanın altında kahramanlar ya da sevilen ve davranışlarıyla iyi örnek teşkil eden şahıslar yer alır. Kahramanlar, ölü ya da diri, gerçek ya da kurgusal olup, karakteristik özelliklere sahip kişilerdir. Bu özellikleriyle bir kültürde saygın kabul edilirler ve rol model olarak hizmet ederler (Hofstede, 2010, ss. 6-8). Kültür farklılıklarının sebebi soğanın iç katmanlarında yer alan ve görünmeyen değerler sisteminde bulunur ancak bir kültür hakkında ilk yargıları bu değerlerin birer davranışa dönüştüğü ve gözlemlenebilir olan dış katmanlardaki tespitler ile oluşur. Davranışların altında yatan asıl sebepler ise değerler sisteminden gelmekte olan kültürel boyutlar ile açıklanır.

Bu çalışmada kültürel boyutların tespiti Geert Hofstede'nin kültürel Boyutlar Kuramında ele aldığı 6 boyut üzerinden yapılacaktır. Geert Hofstede Kültürel Boyutlar Kuramı ile kültürün ölçülebilir bir şey olduğunu ortaya koymaya çalışmıştır. Farklı toplumlarda insanların benzer sorunlarla karşılaşması ancak bu sorunlara farklı çözümler üretmesi kuramının çıkış noktasını oluşturur. 50'den fazla ülkede yapmış olduğu çalışmalar ve anketler ile ülkelerin aşağıda belirtilen kültürel boyutlarda hangi değerlerde olduklarını saptamaya çalışmış ve bu davranışların temellerini açıklamaya çalışmıştır.

Bu boyutlar şunlardır:

- Güç Mesafesi 
Covid-19 Pandemi Döneminde Otomobil Markalarının Reklam Stratejilerinin Yerelleştirme Kapsamında Değerlendirilmesi

- $\quad$ Bireycilik /Kolektivizm (Ortaklaşa Davranışçlık)

- Erillik / Dişilik

- Belirsizlikten Sakınma

- Uzun Dönemli Yönelim - Kısa Dönemli Yönelim

- Serbestlik / Kısıtlama

Güç Mesafesi, bir toplumun, kurumların ve organizasyonların ortaya koyduğu güç dengesini nasıl kabul ettiği ile ilgilidir. Toplum içindeki güç mesafesinin fazla olduğu durumlarda insanlar hiyerarşik düzeni kabul eder. Herkesin bir yerinin olması ve bunun bir açıklamasının olmaması kabul edilen bir durumdur. Toplumun güç açısından en zayıf üyesinin gücü nasıl kabul ettiği ve güç dengelerinin eşit bölünüp bölünmediği üzerine düşünceleri ile ilgilidir. Buradaki temel mesele toplumun insanlar arasındaki eşitsizlikle nasıl başa çıktığıdır.

Güç mesafesi yüksek toplumlarda büyüklere saygı ve itaat, küçüklere karşı korumacılık göze çarpan özelliklerdir. Küçük yaştan itibaren "saygılı davranış" kalıpları öğrenilir ve büyüklere, statü olarak daha yüksektekilere (baba, anne, aile büyükleri, yaşça büyükler, öğretmen, amir) karşı daha edilgen bir duruş toplumsal olarak kabul edilen davranış biçimidir. Toplumsal hiyerarşide piramidin üstündekiler ulaşılmaz ve saygı duyulan kişilerdir. Bu aralığın düşük olduğu toplumlarda bireyler toplum içerisinde eşit bir güç seviyesine sahiptir ve eğitim, gelir, işyerindeki pozisyon gibi etkenler ile daha üst bir statüye erişmek mümkündür (Hofstede, 2010, ss. 63-91). Türkiye bu bağlamda güç mesafesi yüksek toplum özellikleri göstermekteyken Almanya güç mesafesi düşük kültürler arasında yer almaktadır. ${ }^{1}$ Bireycilik/Kolektivizm ise kişilerin kendilerini birey olarak mı bir grubun üyesi olarak $\mathrm{mı}$ hissetmeleri indeksin temel iki ucunu oluşturmaktadır. Bireysellik kavramının yüksek olduğu toplumlarda, bireysel menfaat ve hedeflerin toplumsal menfaat ve hedeflerden önde geldiği söylenebilir. Bu kültürlerde farklı görüşlerin ortaya konması, açıkça tartışıması gerçeğe yaklaşabilmek için yararlı görülür. Kolektivist yapıya sahip toplumlarda grup içi bağlar güçlüdür ve aile kavramı daha geniş kapsamlıdır.

"Biz" odaklı kolektivist toplumlarda grubun dayattığı sorumlulukların yerine getirilmesi gerekli iken odağı "Ben" olan bireyselci toplumlarda birey kendi belirlediği sorumlulukları ya da görevleri yerine getirir ve çekirdek aile olarak tanımlanan aile kavramı yaygındır (Hofstede, 2010, ss. 124-140). Bu boyut bağlamında Türkiye kolektivizm ucuna daha yakın iken Almanya bireycilik ucuna daha yakın bulunmaktadır. Erillik/Dişilik boyutu, cinsiyete dayalı rollerin belirgin olarak ayrılması olarak düşünülebilir. Eril kültürlerde erkeklerin kararlı, sert, maddi yönelimli, kadınların ise alçakgönüllü, duygusal, duyarlı ve narin olmaları beklenir. Cinsiyet rolleri keskin bir şekilde belirlenmiştir. Bu kültürlerde hem genç kızlar hem delikanlılar hırslı ve rekabet yönelimli olmayı öğrenirler. Çocuklar «güçlü olana» hayranlık duyarlar, okulda öğrenciler kendilerini gösterme çabasındadır. Birbirleriyle yarışırlar. İş yaşantııında hırslı, yarışmaya

\footnotetext{
${ }^{1}$ https://www.hofstede-insights.com/product/compare-countries/
} 
hazır bireyler öne çıkar. Bireyin bağımsız ve kendi amaçlarını gerçekleştirebileceği iş yeri ideal görülür. Dişil kültürlerde ise cinsiyete dayalı rollerin birbiriyle değiştiği hem kadınların hem de erkeklerin alçakgönüllü, hassas, narin vs. oldukları kültürlerdir. Bu kültürlerde her 2 cinsiyet de alçakgönüllü, duyarlı vs. olmayı öğrenir. Çocuklara zayıftan ve ezilenden yana olmayı öğretirler. Öğrenciler çalışkan ve gayretli oldukları fikrini uyandırmaya çalışırlar. Terbiye, alçak gönüllülük, dayanışma öne çıkar. Sosyal bağlantılar yardımlaşma iş yerinde ideal görülür.

Eril kültürlerde 1. olma çabası, dişil kültürlerde bireyi gülünç duruma düşürebilir. Çünkü birey güçlü yanlarını dışa vurmaz (Hofstede, 2010, ss. 154-169). Türkiye dişil uca daha yakın iken Almanya ise eril uca daha yakındır. Belirsizlikten sakınma boyutu altında bir kültürün üyelerinin belirsiz veya bilinmeyen durumların tehdidini ne ölçüde hissettikleri anlaşılır. Bu duygu birey üzerinde gerilim yaratmakta ve olacakları önceden bilmek ya da belirsizlikle baş etmeyi etkilemektedir. Şöyle ki, belirsizlikten sakınma derecesi düşük toplumlarda kişiler görev tanımları olmadan da çalışabilirler veya görev tanımlarında olmayan işleri de yaparlar. Karşılaştıkları sürpriz durumları veya sorunları «rastgele» yöntemlerle çözme eğilimdedirler.

Belirsizlikten sakınma derecesi yüksek olan toplumlarda kişiler iletişim sürecinde duygusal, huzursuz, saldırgan davranışlar gösterebilirler çünkü beklenmedik durumlar karşısında kendilerini tehdit altında hissederler. Görev tanımı belli olmalıdır ve her şey kuralına göre çözülmelidir. Belirsizliği kabul etme kapasitesi düşük toplumlarda herhangi bir belirsizliğe karşı kaygı yüksektir ve bu kaygıdan kaynaklı olarak her durumu belirli hale getiren kurallar konulması veya çözümler üretilmesi beklenir (Hofstede, 2010, ss. 204-218). Türkiye belirsizlikten sakınma derecesi düşük toplum özellikleri gösterirken Almanya belirsizlikten sakınma derecesi yüksek bir toplum olarak tanımlanmaktadır. Uzun Dönemli Yönelim - Kısa Dönemli Yönelim, bir toplumun planlama ufku hakkında bilgi sahibi olmamıza yardımcı olur. Toplumların kısa vadeli başarılara mı yoksa uzun süreli çözümlere mi odaklandığı hakkında bilgiler verir. Bu boyutta geleceğe verilen değerle geçmişe verilen değer arasındaki fark dikkate alınır.

Tüm toplumlar geçmişleriyle bağlarını sürdürürken şu an ve gelecekle ilgili meydan okumalarla da başa çıkmalıdırlar. Fakat toplumlar genellikle bu iki amacı farklı şekillerde önceliklendirirler. Kısa dönemli yönelim eğiliminde olan toplumlar genellikle yerleşmiş gelenek ve kuralları korumaya çalışırlar. Sosyal değişime karşı oldukça şüpheci yaklaşırlar. Anında memnun olmak uzun vadede memnun olmaktan daha önemlidir. Kısa dönem odaklı topluluklarda değerler gelecekten çok geçmiş ve şimdiye odaklıdır. Örneğin geçmişten gelen geleneklere saygı veya şu andaki toplumsal sorumlulukların ne kadar yerine getirildiği gibi parametreler önem taşımaktadır. Uzun dönemli yönelim gelecekteki ödüllendirmelerin getireceği değerlere odaklanır. İnsanlar sosyal başarı ya da duygusal memnuniyeti kısa vadede geri plana itmeye meyillidirler ki gelecek için hazırlanabilsinler. Bu tarz bir kültürel bakış açısına sahip toplumlar süreklilik, sebat, birikim ve yeni durumlara uyum sağlamaya daha çok önem verirler. Uzun dönem odaklı toplum birimleri daha çok gelecekle ilgili planlar yapmakta çıkarcı davranmakta ve bu çıkarlara göre değerleri şekillenmektedir. Örneğin para biriktirmek, kalıcı olmak veya çıkarları uğruna uyum sağlamak bunların arasında sayılabilir (Hofstede, 2010, ss. 253- 
Covid-19 Pandemi Döneminde Otomobil Markalarının Reklam Stratejilerinin Yerelleştirme Kapsamında Değerlendirilmesi

258). Bu bağlamda, Türkiye kısa dönemli planlama ufkuna sahipken Almanya uzun dönemli planlama ufkuna sahiptir.

Serbestlik/Kısıtlama boyutu ise mutluluğun ölçüsü hakkında bilgi verir. Serbestlik ve kısıtlama bir topluluğun üyelerinin heveslerini, kişisel istek ve arzularını ne ölçüde bastırdığı veya özgürce yaşadığı ile ilgilidir. Bireylerin boş vakitlerinin ne derecede keyif odaklı olduğu, cinselliğin ne derece serbestçe yaşandığı, sigara, alkol gibi keyif verici maddelerin ne ölçüde gündelik hayatta yer aldığı ile ilgilidir. Serbest topluluklar göreceli olarak isteklerini ve heveslerini yerine getirmekte kendilerini özgür bırakmışlardır. Hayattan zevk almak veya eğlenmek gibi faaliyetleri birer doğal insan davranışı olarak ele alırlar. Buna karşı olarak kısıtlama halindeki topluluklarda ise insani zevklerin ve heveslerin katı kurallar tarafından kontrol edildiği görülebilir. Örneğin, Güney Amerika toplulukları oldukça serbest topluluklarken Kuzey Amerika ve Batı Avrupa'da heves ve rahata düşkünlük azalırken orta doğuda özellikle İslami kurallarla birlikte kısıtlama artmaya başladığı ve özellikle uzak doğuda kısıtlılığın çok daha yüksek seviyelere çıktığı söylenebilir.

Kısıtlayıcı toplumlarda otokontrol önem kazanır ve bireyler sosyal normlar doğrultusunda kişisel istek ve arzularını baskılamak zorunda kalırlar. Ahlak, disiplin ve otokontrol bu toplumlarda önceliklidir. Bu toplumlarda katı sosyal normlar ve kurallar mevcuttur. Kişiler bulundukları toplumun bu boyutunu değerlendirip otokontrol uygulamayı öğrenmek durumunda kalır ancak daha serbest kültürlerden gelen kişiler bu normlara vakıf olmadıkları için kendilerinden beklenen ölçüde otokontrol uygulamakta zorlanırlar ve olumsuz tepkilerle karşı karşıya kalabilirler (Hofstede, 2010, ss. 300-306). Türkiye kısıtlayıcı toplumlar arasında yerini alırken, Almanya serbest toplumlar arasında yerini almaktadır.

Seçilen örnekler son olarak reklam çevirisi kapsamında dilsel ve kültürel aktarım açısından Skopos Kuramı ışığında değerlendirilecektir. Metinlerin işlevlerini dikkate alan yaklaşımlar arasında en fazla öne çıkan Alman çeviribilmci Hans Vermeer'in Skopos kuramıdır. Skopos, Yunanca kökenli bir sözcük olup, "amaç/hedef" anlamına gelmektedir (Reiss ve Vermeer, 1991, s. 95). Çeviri metinlerde metinler arası dilbilimsel tutarlılığın korunması elbette önemlidir. Ancak reklam çevirilerinde izlenmesi gereken strateji metin içi kültürel tutarlılı̆ın önüne geçmemelidir. Reklamlar genellikle kültürel olarak uyarlanır ve metin içi tutarlılı yoluyla maksimum ikna edici etki öncelik kazanır ve böylece metinler arası dilbilimsel tutarlılık ikincil hale gelir (Reiss ve Vermeer, 2014, s. 104). Reiss'ın çeviri odaklı metin sınıflandırması yaklaşımına göre bir metnin yapısı o metnin çeviri stratejisini belirler. Reiss, metinleri işlevlerine göre sınıflandırır ve reklam metinleri çağrı işlevi olan metinler sınıflandırmasına girer (Stolze, 2008, s. 112). Çağrı işlevi olan metinlerin temel işlevi okuyucuyu bir eyleme yönelterek davranışı üzerinde etkili olmaktır. İşlevin merkezinde harekete geçmesi beklenen bir birey olduğuna göre, bu bireyin kendisini harekete geçirecek mesajın kültür kodları aracılığıyla iletilmesi gerekmektedir.

Reklam çevirilerinde farklı stratejiler mümkündür. Bunlardan birincisi halihazırda var olan bir ürünün reklamının diğer ülkelere salt dilsel bir uyarlama ile 
çevrilmesidir, burada sadece dilsel bir adaptasyon söz konusudur. íkinci seçenek ise, birinci seçenekteki yönteme ek olarak reklam metninin kültürel olarak da uyarlanmasıdır. Bu durumda örneğin metin üzerinde değişiklikler yapılabilir, ses, ton, ifade gibi detaylar gözden geçirilebilir. Çoğu zaman en etkili olan ve amacına ulaşan üçüncü yöntem ise glokal reklam seçeneği ile yeni bir pazara uygun yeni bir reklamın oluşturulmasıdır ve bu yöntem de çeviri bilimin yerelleştirme başlığı altında ele aldığı bir uyarlama yöntemidir. Araştırmada markaların bahsedilen stratejilerden hangisini veya hangilerini tercih ettiği gerekçelendirilecektir.

\section{Bulgular}

\subsection{Audi}

Illk reklam otomobil sektörünün lider firmalarından biri olan Alman markası Audi'ye aittir. Audi Covid-19 kapsamında ilk videosunu 26 Mart 2020 tarihinde resmi Twitter hesabından yayınlamıştır. Markanın: "Keep your distance - stay together. Only together we make the difference. \#AudiTogether postuyla ve \#AudiTogether" etiketiyle yapmış olduğu paylaşımda beyaz bir arka plan üzerinde siyah logo ve yazılar bulunmaktadır. Videoya ait ekran görüntüleri soldan sağa sıralanmış şekilde aşağıda gösterilmiştir.

Çok basit ve yalın tasarlanmış bir reklam olarak dikkat çeken paylaşım özellikle hastalığın bulaş riskini azaltmak için büyük önem arz eden sosyal mesafeye vurgu yapmaktadır. İzleyiciye ilk sekansta firmanın iç içe geçmiş dört halkadan oluşan logosu gösterilir. Bu halkalar yavaşça birbirlerinden uzaklaşmaya başlıyorlar ve birbirleri ile olan temasları ortadan kalktığında "KEEP YOUR DISTANCE" yazıcı ortaya çıkar. Akabinde halkalar tekrar birleşir ve "STAY TOGETHER" yazısı belirir. Bir sonraki sekansta firmanın logosu yer almaz ve "stay at home, keep your distance, be healthy, support each other - we are in this together" yazısı izleyicinin karşısına çıkar. Son olarak, "what defines us is our passion for progress and our deeply routed faith in the future. Together we are going to shape it" yazısı yer alır ve iç içe geçmiş logo ve altında \#AudiTogether etiketiyle reklam sona erer.

Audi'nin söz konusu reklamında ilk dikkat çeken unsur kullandıkları dildir. Alman bir firma olan Audi gerek resmi Twitter hesabından gerek Youtube kanalından yayınlamış olduğu videoda İngilizceyi tercih etmiştir. Audi her ne kadar Alman markası olsa da kurumsal dillerinin İngilizce olması, reklamda İngilizce kullanılmasını açıklamaktadır. Firma tüm dünyaca kabul görmüş ve herkesin anladığı varsayılan İngilizce ile sınırların ötesinde bir mesaj vermeyi hedeflemiş olabilir. Firma reklam olarak değerlendirilen bu paylaşımıyla özellikle evde kal, sağlıklı kal ve sosyal mesafeyi koru çağırısından sonra bu zorluğu aşmak için de tüketicisinin yanında olduğunu ve birlikteliği vurgulamaktadır.

Firma yine aynı mecra üzerinden 31 Mart 2020 tarihinde benzer bir paylaşım daha yapmış ve 31 Mart tarihli paylaşımda "The best assistant: Looking out for each other. Keep your distance but stay together" postu ve \#AudiTogether \#StayHome etiketleri yer almıştır. Bu yeni paylaşımda ilk videodan farklı olarak dikkat çeken nokta, birbirlerinden uzak duran halkalar yakınlaştıkça araçlarda bulunan uyarı sensörü sesinin 
Covid-19 Pandemi Döneminde Otomobil Markalarının Reklam Stratejilerinin Yerelleştirme Kapsamında Değerlendirilmesi

hızlanmasıdır. Halkalar tehlikeyi fark ederek tekrar uzaklaşınca uyarı sesi de yok olur ve araçlardaki akıllı sürüş asistan sisteminin en iyisinin kişilerin birbirlerini korumaları olduğu vurgulanır. Son olarak "mesafeni koru" ve "birlikte kal" mesajlarıyla video sonlanır.

Her iki videoda yer alan mesafeyi koru ve bu şekilde bir arada kal mesajı bir tezattır. Birbiri ile çelişen, zıt ifadelerin bir araya gelip bir anlam oluşturması açısından "mesafe" ve "birlikte" kavramları Covid-19 Pandemisi boyunca sıklıkla karşılaşılan bir durumdur. Mesajın halkalardan oluşan göstergelerle verilmesi ise çok akıllıca düşünülmüş bir stratejidir ve araçlarda bulunan uyarı sensörlerinin dikkat çekici sesi izleyicide aracın güvenliğini çağrıştırmaktadır. Korona virüs salgınına karşı alınabilecek en iyi önlemin, sosyal mesafeyi dikkate almak olması gerçeğine dikkat çekmek için Audi mesafeli halkalı logosuyla dikkat çekmeyi başaran bir marka olmuştur.

Dikkat çeken başka ve önemli bir husus ise, markanın Singen, Rostok, Augsburg, Hannover gibi yerel Twitter hesapları üzerinden aynı reklamın Almanca versiyonunun paylaşılmasıdır. Özellikle iç pazara hitap edilen mecralarda yine aynı çağrı Almanca "ABSTAND HALTEN" (Mesafeyi koru) ve "ZUSAMMEN HALTEN" (birbirine destek ol) olarak verilmiştir. Daha kısa ve yalın bir video ile siyah fon üzerine beyaz yazılar tercih edilmiştir. İç pazara yönelik Almancanın tercih edilmesi markanın tüketicideki yerli ürün algısını olumsuz etkilememek ve herkes tarafından anlaşılmasının kesinlik arz etmesi açısından tercih edilmiş olabilir.

Markanın Türkiye Twitter hesabı üzerinden 19 Mart 2020 tarihinde, "Evimizden çıkmayalım, mesafeyi koruyalım, sağlıklı kalalım, birbirimize destek olalım." postuyla ve \#FlattenTheCurve \#Audi etiketleriyle yapmış olduğu video paylaşımı Almanya'daki yerel paylaşımlar ile benzerlik göstermektedir. Yine aynı göstergelerle aynı mesaj verilmeye çalışılmıştır ancak "mesafeyi koruyalım" ve "birbirimize destek olalım” çağrıları Türkçede herhangi zıtlığı barındıracak şekilde ifade edilmemiştir. Bu markanın her iki toplum için hazırladığı reklamda ülkeye göre uyarlanmış bir mesaj bulunmamaktadır. Gerek göstergeler gerekse dilsel aktarım açısından kaynak metin ve erek metin arasında örtüşme söz konusudur. Marka yerelleştirme yapmayı tercih etmemiş ve çok açık ve net bir strateji benimseyerek her iki topluma da ulaşmaya çalışmıştır.

\subsection{BMW}

Ünlü Alman markası BMW Covid Pandemisi kapsamındaki reklamını 25 Mart 2020 tarihinde BMW Almanya resmi Youtube kanalına yüklemiştir. ${ }^{2}$ Film şeklinde hazırlanan reklam 27 saniye sürmektedir ve reklamda müzik yer almamaktadır.

"Jeder weiss dass wir für Kurven leben. Aber die Kurve, die gerade vor uns liegt ist anders als jede Kurve zuvor. Nur gemeinsam können wir sie meistern, nur gemeinsam können wir sie flach halten."

\footnotetext{
${ }^{2}$ https://www.youtube.com/watch?v=a0CzYRzNXYw
} 
["Bizim virajlar için yaşadığımızı herkes bilir. Ancak önümüzde uzanan viraj (eğri), önceki herhangi bir virajdan (eğriden) farklıdır. Onunla ancak birlikte başa çıkabiliriz, onu ancak birlikte düz tutabiliriz."]

Reklam filmine ait kesitler aşağıda yer almaktadır:

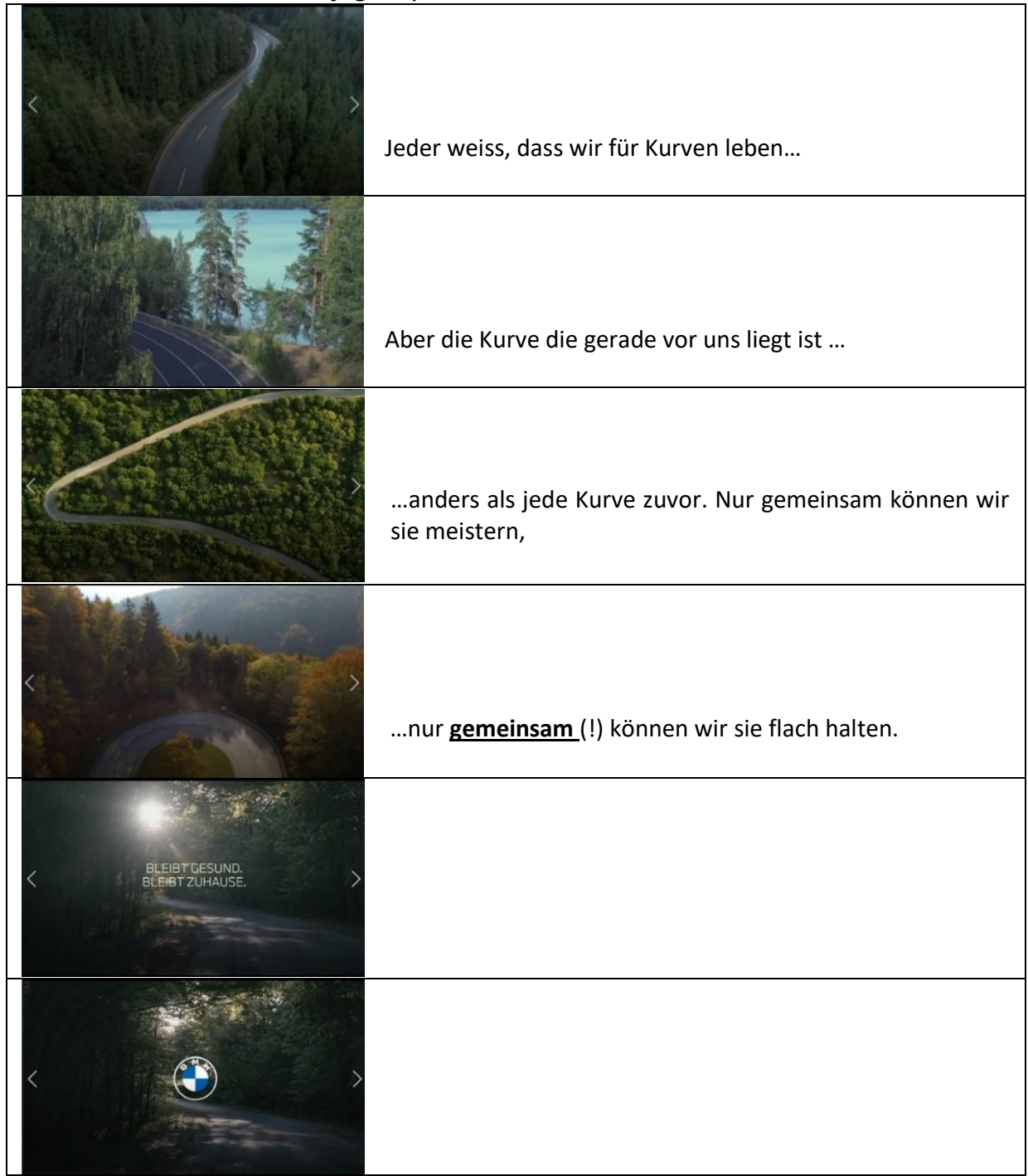

BMW firmasının Almanya için hazırlamış olduğu reklamda özellikle \#WirBleibenZuhause (evde kalıyoruz) ve \#FlattentheCurve (eğriyi düzleştir) etiketleri üzerinden bir söylem geliştirilmiştir. Reklam filminde de bu iki çağrıya vurgu yapılmaktadır. Hız, prestij ve lüksün sembolü sayılan marka, oldukça sakin bir ses 
tonuyla, keskin virajları yüksek hızla alma tutkusundan bahsederek anlatıma başlar. Birer gösterge olan sekanslar, iletinin içeriğine göre değişiyor ve ikinci sekansta keskin bir viraj göstergesi sunulurken, şu an karşılarında bulunan virajın daha öncekilere hiç benzemediği metaforik bir şekilde vurgulanır. Söz konusu olan BMW sürücülerinin yollarda tutkuyla bağlı oldukları keskin virajlar değil, hastalığın bulaş seyrini gösteren grafikteki eğridir ve ancak el ele vererek bu sorunun üstesinden gelinebileceği ve ancak el ele vererek bu eğriyi aşağıya indirmenin mümkün olduğu vurgulanır. "El ele vererek" ifadesinin öneminin altını çizmek için bu ifade yinelenmiştir ve tonlama ile de öne çıkması sağlanmıştır. Ayrıca, eğriyi ancak birlikte düzleştirme mesajı verilirken sonbahar renklerinin hâkim olduğu bir doğa manzarasının tercih edilmiş olması göstergebilimsel çözümleme ile sonbaharın hüzün ve sonları çağrıştırmasından kaynaklanıyor olabilir, çünkü eğri yükselip daha da keskin hale gelirse tıpkı ağaçlardaki yaprakların sararıp solması gibi hastalıktan dolayı hayatını kaybeden insanların sayısının da artacağı çağrışımı amaçlanmış olabilir. "Sağlıklı Kal" ve "Evde Kal” çağrıları ile huzur veren bir doğa manzarasında reklam filmi sonlandırılırken ağaçların arasından güneşin parlaması sembolik olarak dikkat çeken bir unsurdur ve izleyiciye metaforik bir şekilde umut mesajı vermektedir. Son olarak, BMW logosu belirir ve reklam sona erer.

İleti tamamen doğa üzerinden oluşturulmuştur, reklamda ne bir insan ne de bir taşıt kullanılmıştır ve doğanın gücü karşısında insanların acizliği vurgulanarak durumun ciddiyetine vurgu yapılmak istenmiş ve metafor olarak insansız bir dünyanın anlamsızlığına da vurgu yapılmak amaçlanmış görünmektedir. Reklamın kültürel analizinde Hofstede'nin belirsizlikten kaçınma ve kolektivizm boyutları öne çıkmaktadır. Belirsizlikten kaçınma boyutu ile bilinmeyen karşısında hissedilen tedirginlik ve korku sebebiyle belirsizliği bir an önce kontrol altına alarak güveni sağlamak bu koda gizlenmiş mesajlar olarak yorumlanabilir. Kolektivizm boyutu ise Alman toplumu için alışılagelmiş bir tercih değildir. Bireyci toplum boyutunda yer alan Almanlar için toplumun çıkarlarının bireysel tercihlerinin önüne geçmesi ve bireysel tercihlerinden vazgeçerek, toplumun menfaatleri doğrultusunda hareket etme vurgusu ile, pandemi gibi büyük ölçekli felaketlerde toplumun iyiliği için gerekli durumlarda bireyin üzerine düşen görevi yapması ile açıklanabilir. Söz konusu reklam birçok kültüre birebir uyarlanırken Türkiye için tercih edilmemiştir. BMW markası, Almanya pazarı için 48 saniyelik duygusal bir reklam daha hazırlatmıştır. ${ }^{3}$

Aşağıda ilgili reklamın sekanslarına ait ekran görüntüleri sunulmuştur:.

\footnotetext{
${ }^{3}$ https://www.youtube.com/watch?v=qwITMVNoMYc
} 


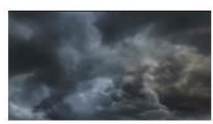

Wir alle steuem durch schwierige Zeiten...

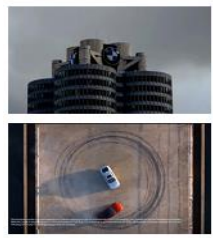

Zeiten in denen Abstand halten der beste Weg ist ..

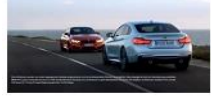

.um Zusammenhalt zu zei gen, ...

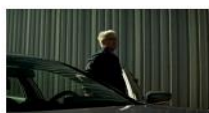

rench
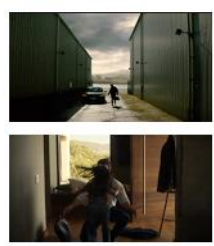

nicht hinter dem Steuer sitzt

in denen der beste Fahrer.

Und wenn wir schon alle zu Hause sind...
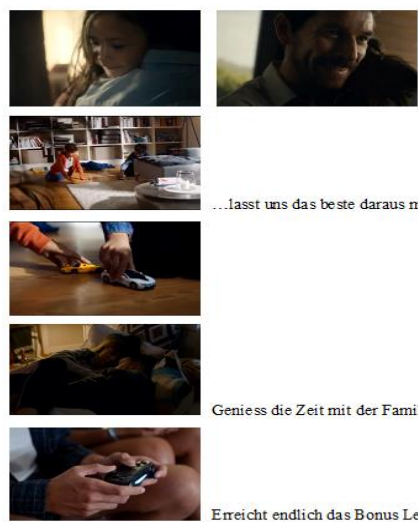

Geniess die Zeit mit der Familie ..
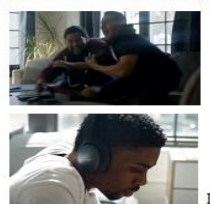
Erreicht endlich das Bonus Leve1. ...

Hört die Geschichten für die ihr nie Zeit hattet ...
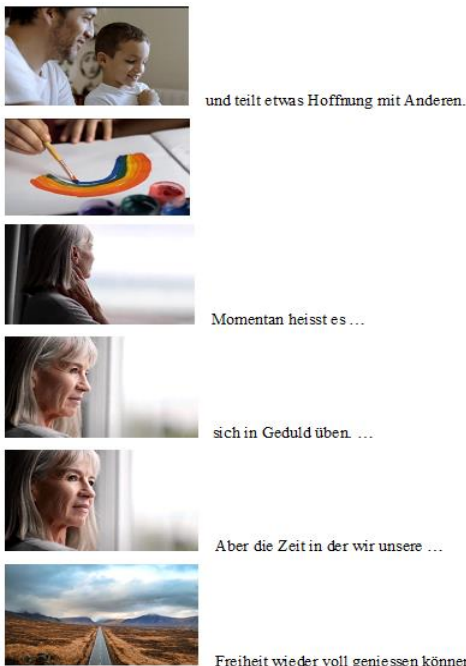

Aber die Zeit in der wir unsere

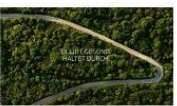

Freiheit wieder voll geniessen können wird kommen 
Covid-19 Pandemi Döneminde Otomobil Markalarının Reklam Stratejilerinin Yerelleştirme Kapsamında Değerlendirilmesi

Reklam, "\#Durchhalten, \#WirBleibenZuhause ve \#BleibtGesund" [\#Dayanmak, \#evdekalıyoruz, \#sağlıklıkalın] etiketleriyle paylaşılmıştır ve reklamın içeriği bu çağrılara uygun şekilde hazırlanmıştır. Reklam filmi hızlı hareket eden kara bulutlarla kaplı bir gökyüzü görüntüsü ile başlar ve sakin bir kadın sesi "Wir alle steuern durch schwierige Zeiten." [Şu sıralar hepimiz zor bir süreçten geçiyoruz] cümlesiyle görseli destekleyen bir anlatıma başlarken bilinçli olarak kullanılan "steuern" fiili dikkat çekmektedir. Bu fiil burada geçmek veya yönetmek anlamında kullanılmış olsa da aslında birincil anlamı sürmek, (taşıt) kullanmak, dümen kullanmak, anlamında taşıt bağlamlı bir kullanımdır. Kasvetli gök yüzü pandemi dönemi için bir metafor anlamı taşımaktadır. "Schwierige Zeiten" [Zor zamanlar] ifadesi işitilirken ekrana BMW firmasının Münih'teki ana merkez binası gelmektedir. "Zeiten in denen Abstand halten der beste Weg ist um Zusammenhalt zu zeigen" [Birlikteliği korumanın en iyi yolunun mesafeyi korumak] söylemi esnasında ekranda firmanın daha önceki reklamlarından alınmış ve araçların ön plana çıktığı ancak metaforik olarak sosyal mesafeye vurgu yapan sahneler göze çarpmaktadır, konuşmada "...in denen der beste Fahrer...nicht hinter dem Steuer sitzt" [En iyi sürücü, bu dönemde, araç kullanmayan sürücüdür] vurgusu yapılırken görselde bir erkeğin aracından inip, evine gittiği ve kendisini heyecanla bekleyen küçük kızına sarıldığı sahne ile bir süre mobil olmaktan vaz geçilmesi çağrısı ile tamamlanır. Bu noktadan itibaren reklamın daha duygusal bir şekil aldığı dikkat çekmektedir. "Und wenn wir schon alle zu Hause sindLasst uns das beste daraus machen" [Madem evlerimizdeyiz, o halde bu durumu en iyi şekilde değerlendirelim] söylemi görselde baba ile kızın birbirine gülümseyerek sarıldığı, 2 erkek çocuğun bir odada BMW marka oyuncak arabalarla oynadığı ve arabaların yakın çekim ile gösterildiği sahnelerle izleyiciye sunulur. "Geniess die Zeit mit der Familie" [Ailenle geçirdiğin zamanın tadını çıkart] ifadesi birbirine sarılmış bir çiftin kanepede sarmaş dolaş duygusal halleri ile pekiştirilir. "Erreicht endlich das Bonus Level" [Daha önce ulaşamadığınız rekor seviyeye ulaşın] söylemi, görselde iki yetişkin erkeğin evde konsol oyunu oynarken hissettikleri coşku ile izleyiciye sunulur ve oyunda seçilen aracın da BMW olması yine bir metafor olarak dikkat çekmektedir. Şu sıralar gerçek bir BMW kullanamayan sürücülerin sanal da olsa bu zevki tatmin etmeye çalışmaları olarak yorumlanabilir. Beyaz bir odada, beyaz kıyafetleri ile tezat oluşturan siyahi bir gencin kulaklıkları ile "Hört die Geschichten für die ihr nie Zeit hattet" [daha önce dinlemeye fırsat bulamadığınız hikayeleri dinleyin] ifadesi ile yine evde kalınan zamanı değerlendirme olanakları ile anlatım sürdürülür. Bir baba küçük oğlu ile resim yaparken kullanılmış "Und teilt etwas Hoffnung mit Anderen" [başkalarına umut olun] ifadesi işitilirken çocuğun sulu boya ile bir kâğıda çizmiş olduğu ve Pandemi döneminde tüm dünyada umudun sembolü haline gelen gök kuşağı resmi çizme sahnesi ile izleyiciye sabır ve umut vurgusu yapılmaktadır.

Filmin devamında beyaz saçlı, yaşlı ve Avrupalı olduğu izlenimi uyandıran bir kadın pencereden düşünceli bir şekilde dışarıyı izlerken, yine umuda atıf yapılarak şu sıralar sabırlı olmanın öncelikli bir anlam taşıdığı ifade edilmesi ve gösterge olarak yüksek risk grubunda yer alan yaşlıların bu sayede korunması mesajı yine retorik bir anlatımla ifade edilmektedir. Kadının başını yukarıya kaldırması ile daha umutlu bir ses ve ifadeyle, "Aber die Zeit in der wir unsere Freiheit wieder voll geniessen können wird kommen" [özgürlüklerin tekrar sonuna kadar yaşanacağı zamanların geleceği] vurgusu kırsal bir 
coğrafyanın ortasında dümdüz bir çizgi olarak uzanan yol göstergesi ile müziğin hareketlenip bir anda tekrar sakin bir tonla devam etmesi ile göstergebilimsel çözümlemesi umut olan yeşil ağaçların olduğu bir sahneye geçer. Ağaçların ortasında keskin bir viraj görülmektedir ve ekranın ortasında "BLEIBT GESUND - HALTET DURCH" [SAĞLIKLI KALIN-SABREDIN] yazısı belirmektedir ve reklam filmi "Diesmal müssen wir zu Hause bleiben um das Ziel zu erreichen" [bu sefer amacımıza ulaşabilmemiz için evlerimizde kalmalıyız] mesajı ile son bulur. Son sahnede siyah bir fon üzerinde BMW logosu ile markaya vurgu yapilır.

Reklam filminde dilsel olarak en çok dikkat çeken unsurlar metafor kullanımı ve retorik anlatımdır. Kültürel boyutlar olarak değerlendirildiğinde ise ağırıklı olarak Bireyselci toplum boyutu öne çıkmaktadır. Reklamda aile kavramının önemi vurgulanmaktadır ancak bireyselci toplum geleneğinde hâkim olan çekirdek aile ile yapılır bu vurgu. Reklamdaki karakterler ya tek başlarına ya da en fazla iki kişilik gruplar halinde gösterilmiştir. Sosyal mesafe vurgusu yapıldığı için kalabalık grup göstermekten çekinilmiş olunabilir ancak ev içinde aile üyeleri de bireysellik vurgusu ile ele alınmıştır. Markanın Türkiye reklamı \#hayatbizibekliyor etiketi vurgusu ile hazırlanmıştır ve 30 saniye sürmektedir.

Aşağıda soldan sağa doğru sekanslara ait ekran görüntüleri yer almaktadır.

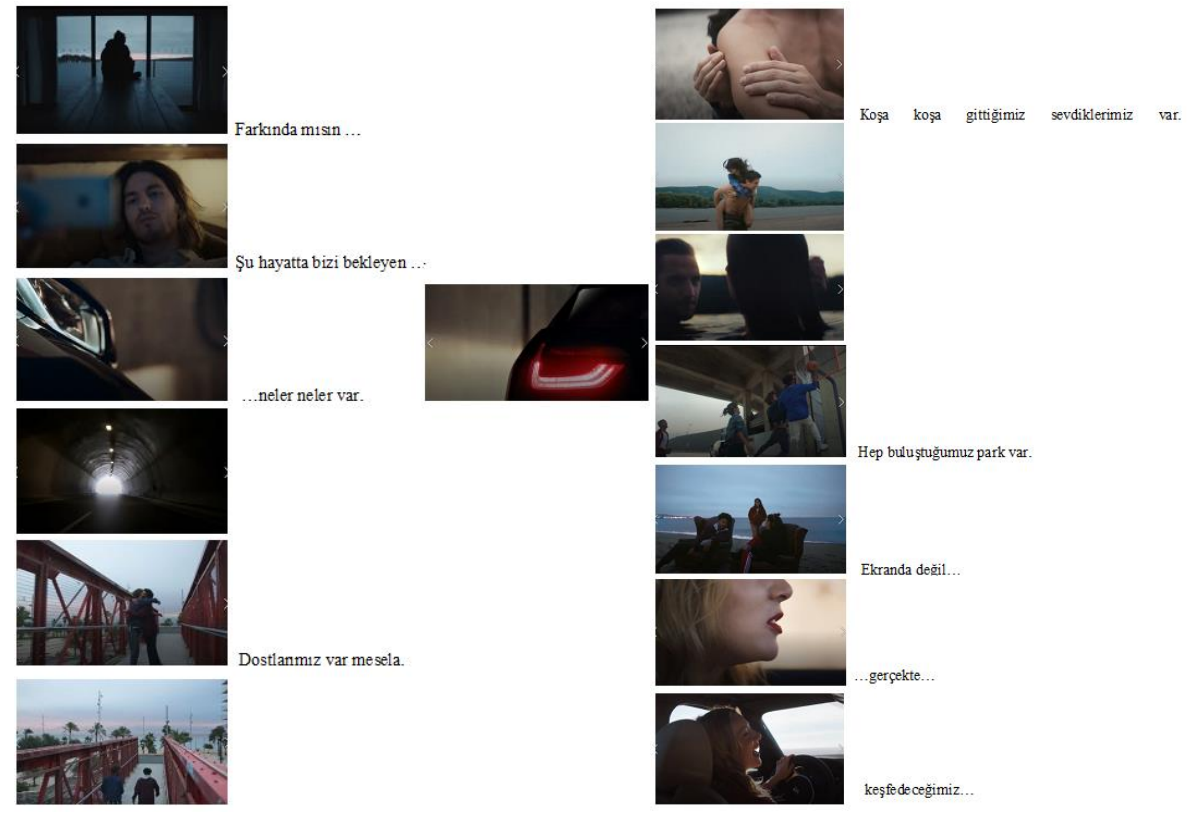




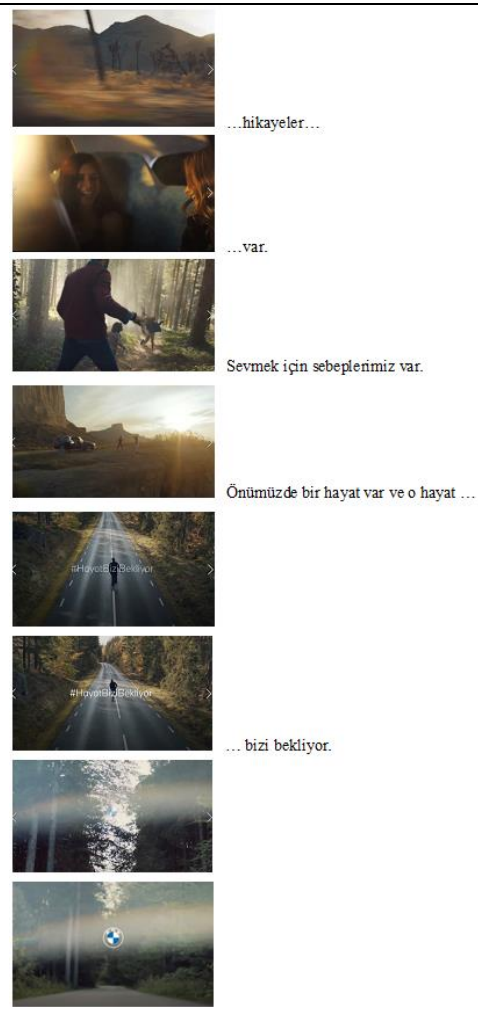

Reklamın ilk sahnesinde arkası dönük bir genç iskeleyi anımsatan bir platform üzerinde oturmuş dışarıyı izlemektedir. Ortalık pek aydınlık olmamasından sabah veya akşamüzeri olduğu anlaşılmaktadır. Hemen bir sonraki sekansta genç olduğu belli belirsiz anlaşılan bir erkek loş bir odada tek başına oturmakta, dışarıda yağmur yağmaktadır. Reklamda gerek görseller gerek anlatım ve müzikle ağır bir hava oluşturulmuştur. Bir sonraki sekansta yine genç bir erkek uzandığı yerden elindeki telefona bakmaktadır ve tüm sahneler hızlı bir şekilde birbiri ardına gelirken "Farkında mısın şu hayatta bizi bekleyen neler neler var "cümlesi esnasında BMW marka bir aracın farları yanar ve hemen sonrasındaki sahnede tünelden hızlı bir çıkış dikkat çekmektedir. Tünelden çıktıktan sonra hayata anlam katan birtakım değerlere vurgu yapılır. "Dostlarımız var mesela" ifadesi esnasında birbirine sarılan iki erkek, "Koşa koşa gittiğimiz sevdiklerimiz var" cümlesi ile de sahilde bir kadın elini üst bedeni çıplak bir erkeğin kolunu okşar. Daha sonra sahilde kadını sırtına almış koşan ve eğlenen bir çift belirir ekranda ve denizin içinde birbirine aşkla bakarken, "hep buluştuğumuz park var" ile dört gencin bir potaya basket atmasıyla kalabalık bir sahneye hızlı bir geçiş yapılır. Kumsalda, evlerde görmeye alışık olduğumuz berjer koltuklarda oturan gençler belirirken, "ekranda değil, gerçekte keşfedeceğimiz hikayeler var" cümlesi esnasında sekanslar hızla değişmekte ve bir otomobilde eğlenerek yolculuk eden gençler görülür. "Sevmek için sebeplerimiz var" ile 
ekrana bir baba ve iki çocuk orman yürüyüşü ile çıkmaktadır. Bir sonraki sahnede ise "Önümüzde bir hayat var ve o hayat..." ifadesi ile ailelerin veya seyahat etmeyi seven kullanıcıların tercih edeceği SUV tarzı büyük bir BMW aracı bir uçurumun kenarına çekmiş ve kollarını açarak kendilerini beklediği seslendirilen hayata kucak açtıkları şeklinde yorumlanması mümkün olan bir sahne ile son sekansa geçiş yapılır. Son sahnede bir genç kaykayı ile ormanın ortasında sonu viraj olan düz bir yolda ilerlemektedir ve ekranın ortasında \#HayatBiziBekliyor etiketi ile son bulurken ağaçların arasındaki aydınlıktan BMW logosu ekrana kayarak girer.

Reklam filminde kavramların düz anlamlarıyla kullanılmış olduğu dikkat çekmektedir. Göstergelerde dikkat çeken unsurlar deniz, orman, uçurum ve evdir. Deniz edebi ve mitolojik anlamda çoğu kez hayatın anlamı ve akışı olarak yorumlanmaktadır. (Tekin, 2018, ss. 110-111) Dünyayı etkisi altına alan bir pandemi döneminde yaşam ve hayatta kalma daha büyük anlamlar ifade etmektedir ve reklamda bu istek deniz sembolü ile gösterilmiştir. Pandemi gündeminde hâkim olan karamsarlık veya monotonluk yerine, gelecekteki hareketli ve eğlenceli anlara odaklanan reklamda sosyal mesafe ya da herhangi bir sorumluluğa vurgu yapılmamaktadır. Kültürel açıdan ele alındığında ise Türk reklamlarında pek alışık olmadığımız bireysellik vurgusu dikkat çekmektedir. Kalabalık aile yerine, gençlerin bireysellikleri, dostlukları, aşkları ve eğlenme güdüleri öne çıkmaktadır. Aile kavramı baba ve iki çocuğu ile orman yürüyüşü ile sınırlıdır. SUV tarzındaki büyük aile aracı ise daha çok maceracı gezgin ruhlu sürücüleri hedeflenmektedir. Bireyselci toplum boyutunun dışında Hofstede'nin altıncı boyutu olan serbestlik / kısıtlama boyutuyla da açıklanabilir. Reklamda gençlerin hayat bizi bekliyor sloganıyla daha haz ve özgürlük odaklı bir yaşam tarzı benimsedikleri şeklinde değerlendirilebilir. Bu tercih, BMW marka araçların hız, tutku ve enerji ile bağdaştırılmasından kaynaklandığı şekilde yorumlanabilir.

Çeviri stratejisi olarak ele aldığımızda ise Almanya'da gösterilen reklamdan çok farklı bir senaryo ve etiket ile karşılaşıyoruz. Türk pazarı için glokal reklam seçeneği ile yeni bir reklam oluşturulmuştur ve bu yöntem de çeviri bilimin yerelleştirme başlığı altında ele aldığı bir uyarlama yöntemidir.

\subsection{Mercedes-Benz}

Mercedes-Benz markası Alman pazarı için 40 saniye süren \#flattenthecurve, \#stayhome ve \#danke etiketleri ile oldukça yalın ancak etkili bir reklam hazırlamıştır. ${ }^{4}$ Aşağıda reklamın her bir sekansının ekran görüntüsü soldan sağa verilmiştir.

${ }^{4}$ https://www.youtube.com/watch?v=-0FW06RoW-o 
Covid-19 Pandemi Döneminde Otomobil Markalarının Reklam Stratejilerinin Yerelleştirme Kapsamında Değerlendirilmesi
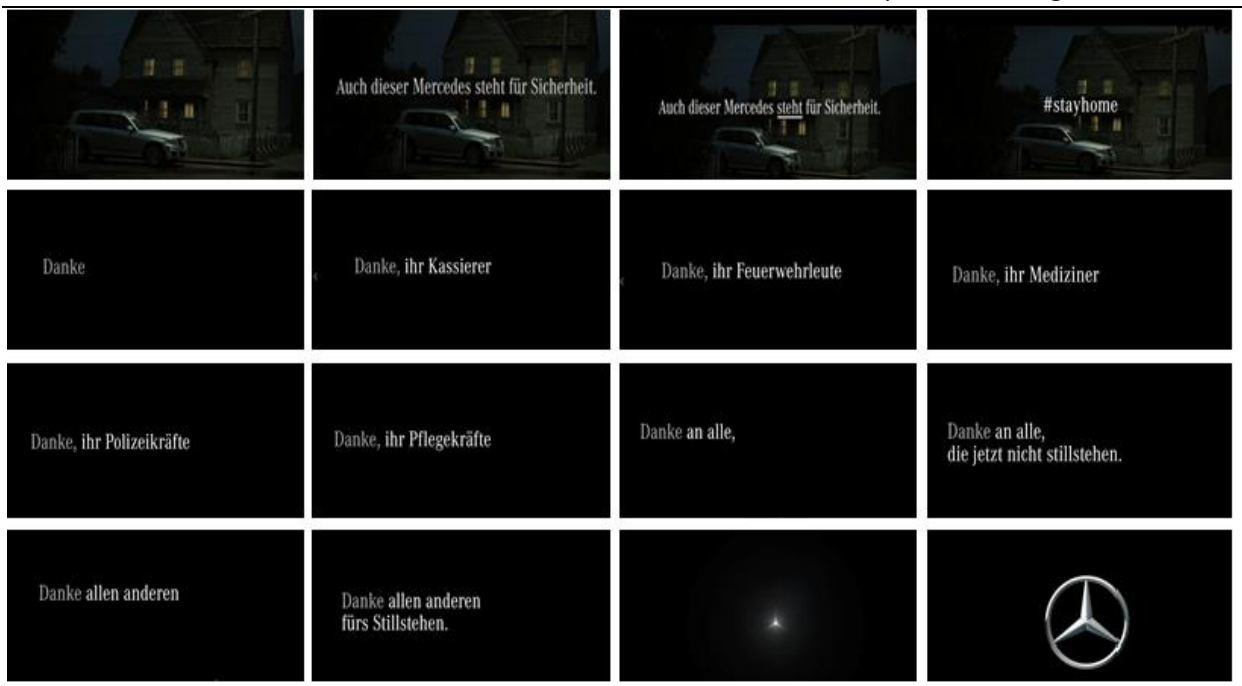

Mercedes aslında oldukça basit, direkt ve yalın bir reklam ile mesajını vermektedir. Marka bir taraftan hastalıktan korunmak için mobil olmaktan vaz geçerek evlerde kalmanın önemini vurgularken, diğer taraftan da hayatın devamı için kendini riske atarak evinde kalamayanlara teşekkür ederek motivasyon vermeyi amaçlamaktadır.

Reklamın ilk karesinde gece vakti sessiz bir şekilde eski ve geleneksel bir Alman evinin önünde park edilmiş bir Mercedes-Benz marka bir araç görülmektedir. Ekranda "Auch dieser Mercedes steht für Sicherheit" [Bu Mercedes de güvenlik için duruyor] yazısı beliriyor ve "steht" [duruyor] kelimesinin altı çiziliyor. Bu vurgu ile aslında kelime oyunu yapılmaktadır ve mobil oldukları süre boyunca makbul sayılan ve o zaman güvenliğin öncelikli olduğu otomobillerin mevcut durumda "durarak" güvenliğe katkı sağladıkları mesajı verilmek istenmiştir. Dördüncü karede \#stayhome etiketi ile evde kalın çağrısı yapıldığı görülmektedir. Bundan sonraki her bir karede marka kendi hayatlarını riske atan ve ülkeyi ayakta tutan herkese teşekkür etmeye başlar. Kasiyerlerle başlayarak sırasıyla itfaiyeciler, doktorlar, güvenlik güçleri, sağlık çalışanları ile devam ederken, şu an durmayan herkese "Danke an alle die jetzt nicht stillstehen" cümlesiyle teşekkür ettiklerini ifade ettikten sonra "Danke allen anderen fürs Stillstehen" [geri kalan herkese durdukları için teşekkürler] şeklinde kelime oyunuyla evinde kalanlara da teşekkürlerini iletir. Reklam boyunca gece sessizliği hakimdir ve sadece 3 kere köpek havlaması duyulur.

Marka bu reklam ile çok net ve etkili reklam yapabilmenin de mümkün olabildiğini göstermektedir. Aynı reklamın İngilizce versiyonu dünyanın birçok ülkesinde gösterilirken Türkiye pazarı için aynı reklam salt dilsel bir aktarımla Türkçeye uyarlanmıştır. Türkiye için hazırlanan reklamda orijinaline uygun şekilde \#EvdeKal ve \#Teşekkürler etiketi kullanılmıştır. 32 saniye süren reklamın ekran görüntüleri aşağıda 
soldan sağa doğru verilmiştir. ${ }^{5}$ Reklamda orijinalinde olduğu gibi gece sessizliği hakimdir ve sadece 2 kere köpek havlama sesi duyulur.
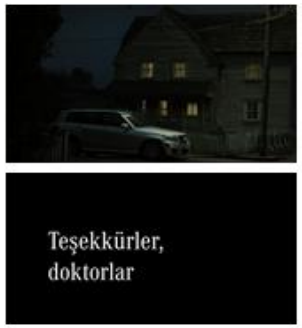

Teşekkürler,

kasiyerler

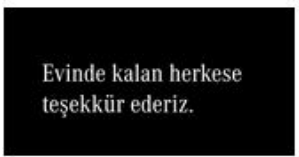

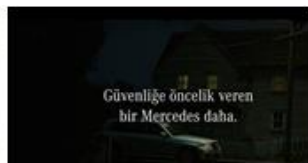
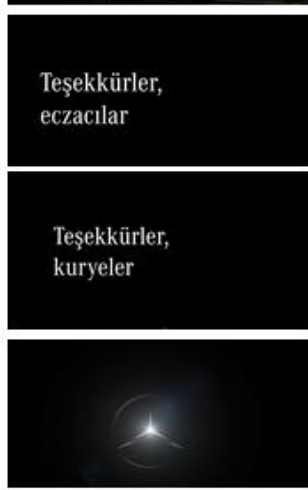
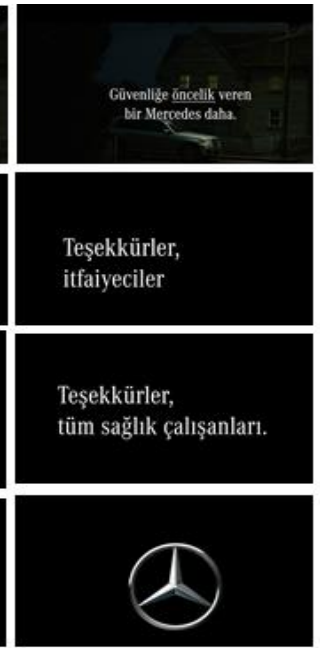
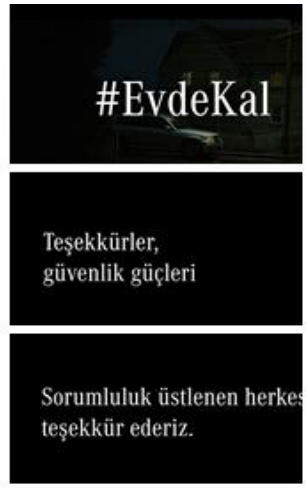

Türkiye için hazırlanan reklamda sadece "teşekkürler" yazan kare eksiktir ve yazılar daha hızlı bir şekilde akmaktadır. Bunun nedeni reklamın süresini kısaltarak maliyeti düşürmek olabilir. Illk dört karede orijinalindeki görselin aynısı mevcuttur. İkinci karede "Güvenliğe öncelik veren bir Mercedes daha" yazısı görülmektedir ve bir sonraki karede "öncelik" kelimesinin altının çizildiği dikkat çekmektedir. Orijinal metinde yapılan kelime oyununa Türkçe de yer verilmemiştir. Türkçe reklamda sırasıyla doktorlara, eczacılara, itfaiyecilere, güvenlik güçlerine, kasiyerlere, kuryelere ve tüm sağlık çalışanlarına teşekkür edilmektedir. Hayatın devamını sağlayanları "Sorumluluk üstlenen herkes" olarak ifade etmeyi uygun görmüşlerdir.

Orijinalinde kelime oyunu ile ifadenin zenginleştirildiği cümleler aşağıda yer almaktadır.

1. Auch dieser Mercedes steht für Sicherheit [Güvenliğe öncelik veren bir Mercedes daha]

2. Danke an alle die jetzt nicht stillstehen [Sorumluluk üstlenen herkese teşekkür ederiz]

3. Danke allen anderen fürs Stillstehen [Evinde kalan herkese teşekkür ederiz]

Bir dilden farklı bir dile aktarım yapılırken kelime oyunları ile ifadeyi zenginleştirmek her zaman mümkün olmayabilir. "Stehen" fiilinin, durmak, bulunmak, ayakta durmak, olmak gibi karşılıkları bulunmaktadır. Türkçede benzer bir kelime oyunu yapmaya olanak sağlayan bir fiil bu cümle için pek olanaklı görünmemektedir. Dolayısıyla vurguyu "öncelik" kelimesine yaparak doğru bir strateji izlenmiştir. Genel olarak doğru bir çeviri stratejisi izlendiği ifade edilebilir.Türkçe reklamda dikkat çeken en önemli husus ise minnet duyularak teşekkür edilen meslek gruplarının sıralamasıdır.

${ }^{5} \mathrm{https}: / /$ www.youtube.com/watch?v=ub2bJkJwJCk 


\begin{tabular}{|l|l|l|}
\hline & Almanca & Türkçe \\
\hline 1 & Kasiyerler & Doktor \\
\hline 2 & Itfaiyeciler & Eczacı \\
\hline 3 & Doktorlar & Itfaiye \\
\hline 4 & Güvenlik güçleri & Güvenlik Gücü \\
\hline 5 & Sağlık çalışanları & Kasiyer \\
\hline 6 & - & Kurye \\
\hline
\end{tabular}

Görüldüğü üzere Türkçede teşekküre doktor ve eczacılardan başlanmış, itfaiye, güvenlik gücü, kasiyer ve kurye olarak devam etmiş̧ir. Almancasında olmayan eczacılar ve kuryeler Türkçe metne eklenmiştir. Almancada ise teşekküre kasiyerlerden başlanarak, itfaiyeciler, doktorlar, güvenlik güçleri ve sağılı çalışanları olarak devam etmektedir.

Bu farklılığı kültürel kodlarla açıklamak mümkündür. Hofstede'nin birinci boyutu olan Güç Aralığı sosyal adaletsizlik, hiyerarşiye duyulan saygı ve gücü elinde bulunduran prestijli çevreler ile ilgilidir. Türkiye Güç Aralığı yüksek ülkeler arasındadır $(\% 66)^{6}$ ve beden gücü veya daha düşük eğitim düzeyi ile icra edilen meslekler saygın kabul edilmez ve hiyerarşi piramidinin altlarında yer alır. Ancak Almanya Güç Aralığı düşük (\%35) bir ülke olarak beden gücü veya eğitim düzeyi ile ilgili bir saygınlığa o kadar önem vermez. (Hofstede, 2011, s. 76) Bu sebeple Türkçe reklamda prestijli sayılan mesleklerin yukarıdan aşağıya sıralanması uygun görülmüş olabilir. Bir diğer ve daha iyi niyetli bir açıklaması ise Korona virüsü ile mücadelede sahada en aktif ve tehlikeli mücadeleyi veren meslek gruplarına ayırmış olmalarıdır. Ancak bu durum kasiyer ve kuryelerin en sonda yer almasını yine de açıklayamaz.

\subsection{Volkswagen}

Volkswagen pandemi döneminde Almanya için 50 saniye süren oldukça yalın bir reklam hazırlamıştır. Mavi bir fon üzerinde "Wir" yani "Biz" kelimesi görülmektedir. "Wir" yazısı ekranda hiç değişmezken yanına yeni yazılar eklenmektedir ve yazılara sakin bir enstrümantal müzik eşlik etmektedir. ${ }^{7}$ Aşağıda yer alan ekran görüntüleri soldan sağa doğru sıralanmıştır.

\footnotetext{
${ }^{6}$ https://www.hofstede-insights.com/product/compare-countries/

${ }^{7}$ https://www.youtube.com/watch?v=Qoy3qekveo8
} 
1.

Wir

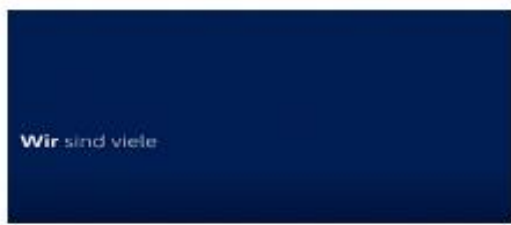

3.

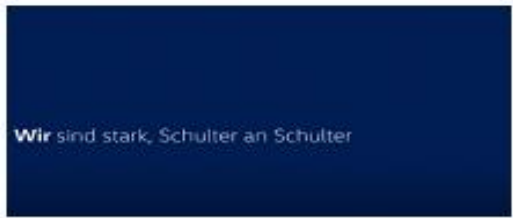

5.

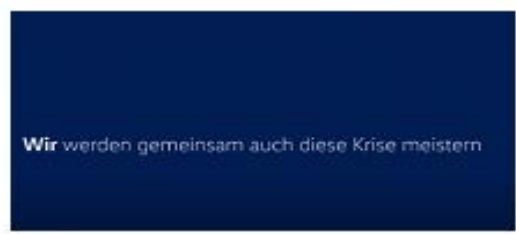

7.

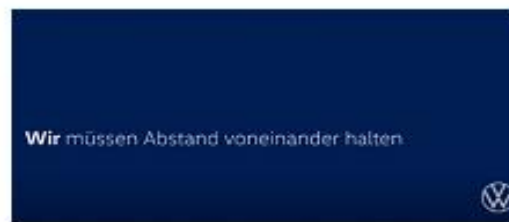

9.

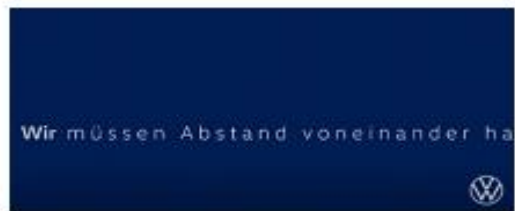

11

(Q)

13.

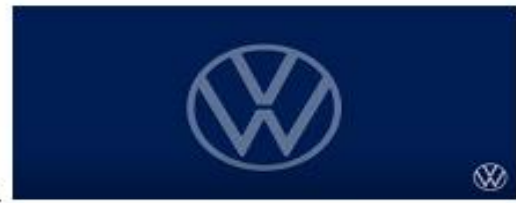

Q

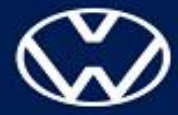

2.

Wir sind Volkswager

2.

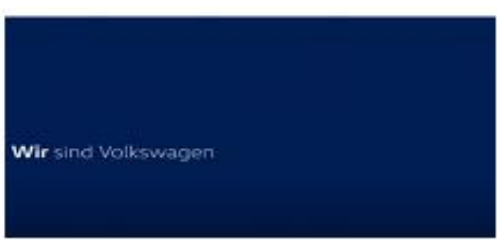

4.

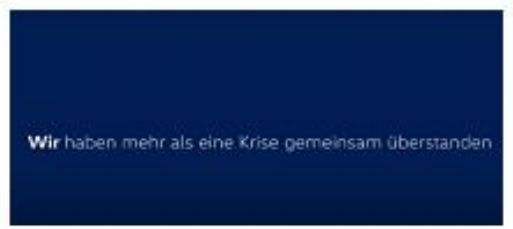

Wir sind Kollegen, Freunde, eine Familie

6

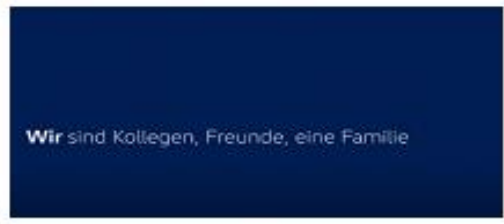

Wir mussen diasmal aber etwas anders machen

8.

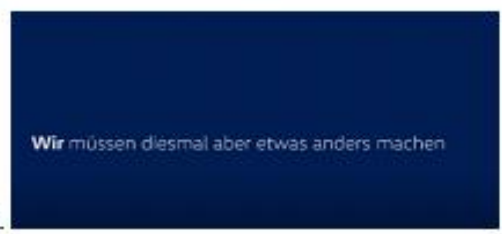

Wir mússen Abstand voneinander hatten

10.

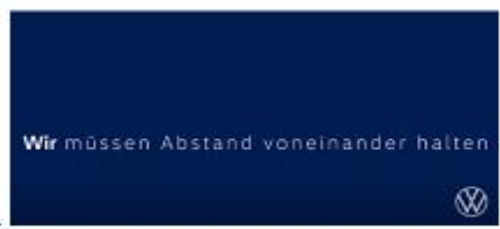

12
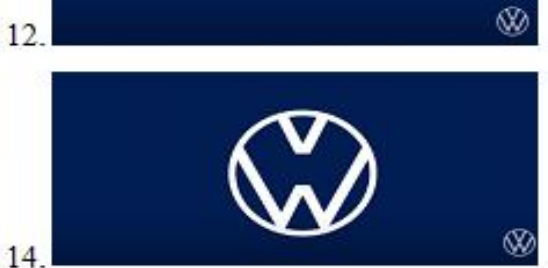

15. 
Her bir ekran görüntüsünün Türkçe açıklaması şu şekildedir:

1. Biz

2. Biz Volkswagen'iz

3. Biz çokuz

4. Biz birlikte birden fazla krizin üstesinden geldik

5. Biz güçlüyüz, omuz omuzayız

6. Biz arkadaşız, dostuz, bir aileyiz

7. Biz birlikte bu krizin de üstesinden geleceğiz

8. Biz bu sefer farklı bir yol izlemek zorundayız

9. Biz aramızdaki mesafeyi korumalıyız

10. Biz aramızdaki mesafeyi korumalıy z

11. (Yazılar ekranın sağına doğru kayarak kadrajdan çıkar)

12. Volkswagen'in klasik logosu ( $V$ ve W harfleri birbirinden uzaklaşır)

13. Volkswagen'in sosyal mesafeli yeni logosu

14. Volkswagen'in sosyal mesafeli yeni logosu daha belirgin

15. Mesafeyi koruduğunuz için teşekkür ederiz

Yalınlığı ile öne çıkan reklamın dikkat çeken diğer bir tarafı da \#FlattenTheCurve ve \#WeNotMe etiketleridir. "Flatten the Curve"ile aynı çatı altında bulunduğu BMW ile aynı sloganı paylaşmaktadır ve aynı şekilde hastalanan insanların sayılarının gösterildiği istatistiklere vurgu yapmaktadır ancak asıl dikkat çeken burada "We not Me" etiketidir ve reklam da tamamen bu slogan üzerine inşa edilmiştir. Almanya bireysellik boyutu oldukça yüksek bir toplumdur. Geert Hofstede'nin ülkeleri karşılaştırdığı skalada Almanya'nın bireysel toplum değerlendirmesinde \%67 bireysellik eğilimi gösterdiği belirtilmiştir. 8 Türkiye aynı değerlendirmede $\% 37$ olarak belirtilmiştir. Bireysel toplumların en büyük özelliği "Biz" değil, "Ben” kültürleri olmalarıdır. Volkswagen, tüm alışkanlıkları alt üst eden pandemi ile Alman toplumunun eğilimine zıt bir vurgu yaparak "Biz" olmayı, birlikte hareket etmeyi ve ancak bu şekilde bu sorunu aşabileceklerini vurgulamaktadır. Her bir bireyin, toplumun menfaatleri için sorumlu olduğu mesajı verilir. Belirsiz durumlar karşısında tedirginliği azaltmak ve sorunun çözümü için birtakım normların belirlenmesi amacıyla özellikle ne yapılması gerektiği ile ilgili bilgi aktarımını içeren bir reklam filmi olması kültürel olarak belirsizlikten sakınma derecesi yüksek bir kültürel boyutun da varlığına işaret etmektedir. 11. ekran görüntüsünde harflerin birbirinden uzaklaşması sosyal mesafeyi görsel olarak da pekiştiren bir strateji olarak reklamda yerini almıştır. Volkswagen, Audi ve Mercedes gibi sosyal mesafenin önemini vurgulamak için logosunu değiştirmiştir hatta bir adım öteye giderek bu değişikliği sadece dijital ortamda değil, yeni araçlarında da kullanma kararı almıştır.

Markanın Türkiye pazarı için hazırlamış olduğu reklam, Alman pazarı için hazırlanan reklamdan tamamen bağımsız bir yerelleştirme örneğidir. 59 saniye süren reklamın etiketi ise \#GüzelGünlerYakın şeklindedir. ${ }^{9}$ Almanya'daki reklama benzer bir

\footnotetext{
${ }^{8}$ https://www.hofstede-insights.com/product/compare-countries/

${ }^{9}$ https://www.youtube.com/watch?v=rgxcGcfGM4s
} 
müzik tercih edilmiştir. Aşağıda reklam filminin ekran görüntüleri soldan sağa sıralanmıştır.
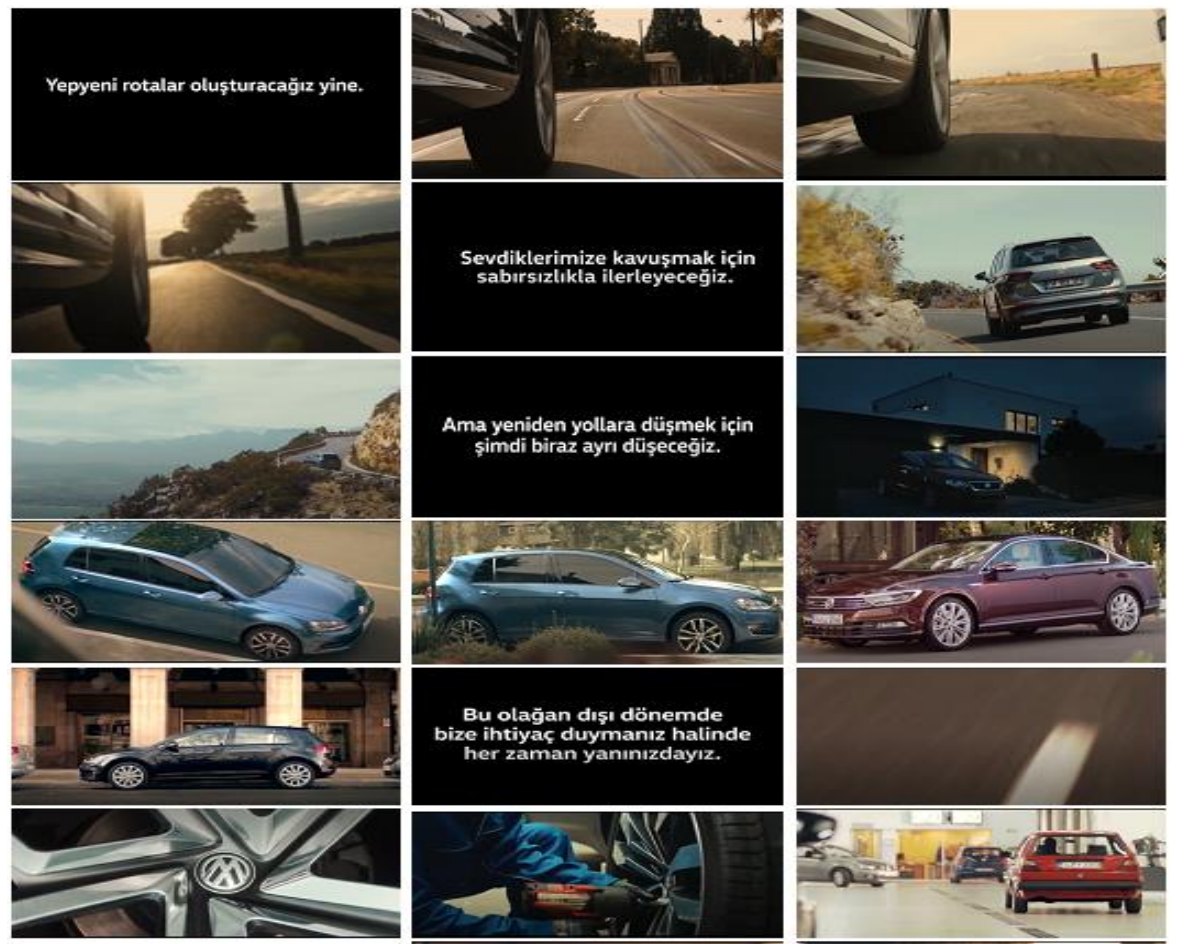

Yolların keyfini yeniden süreceğimiz günler yakın.
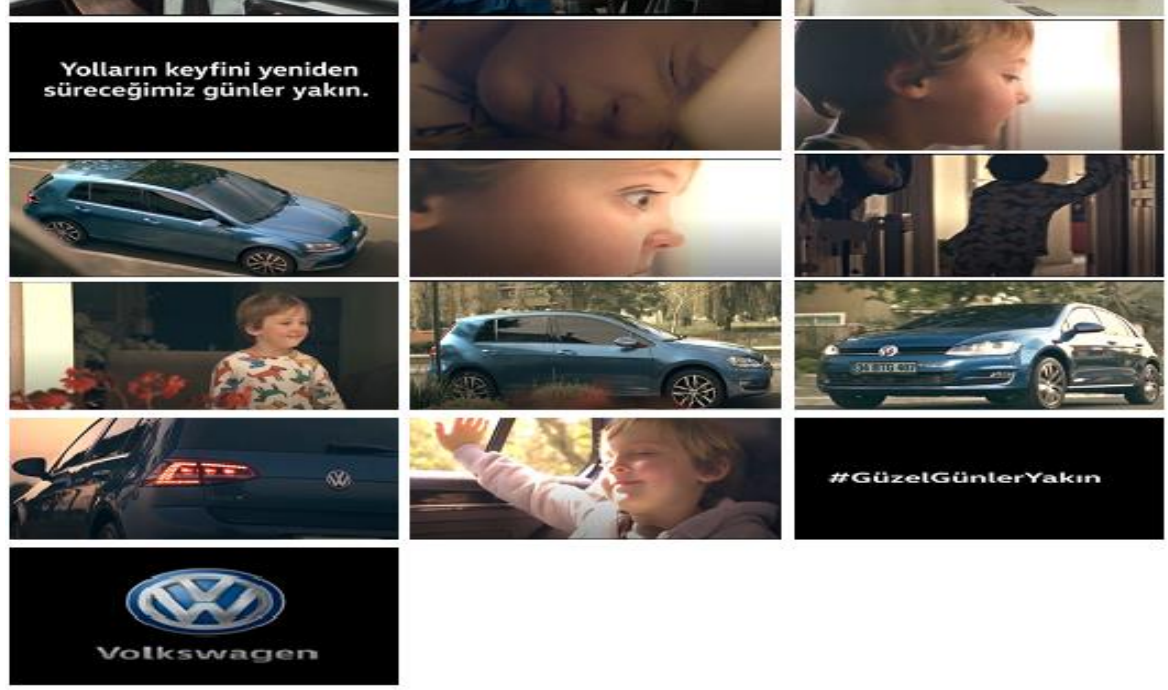

Yukarıda ekran görüntüleri verilen reklam filminde konuşmacı bulunmamaktadır. Mesajlar görseller arasına yerleştirilen siyah fon üzerine beyaz ile yazılmış şekilde verilmektedir. Reklam boyunca geleceğe dair beklentilerin ve güzel günlerin vurgusu yapılırken sosyal mesafeye sadece bir defa "Ama yeniden yollara 
Covid-19 Pandemi Döneminde Otomobil Markalarının Reklam Stratejilerinin Yerelleştirme Kapsamında Değerlendirilmesi

düşmek için şimdi biraz ayrı düşeceğiz" şeklinde bir sözcük oyunu ile yer verilmiştir. İçinde bulunulan zamanda tüm dünyanın mustarip olduğu sıkıntılara vurgu sadece Volkswagen araçların park halinde durmaları ile yapılmıştır. Reklamdaki metafor kullanımı yaşamı sembolize eden deniz imgesi ile ve özgürlüğü sembolize eden gökyüzündeki uçan kuşların kullanılması ile açıklanabilir. Yollara düşmek ve ayrı düşmek deyimleri kullanılmıştır. Reklamda özellikle dikkat çeken bir kültürel boyuta rastlanamamıştır.

\section{Tartışma ve Sonuç}

Incelenen 4 markanın reklamlarında 4 ayrı strateji göze çarpmaktadır. Audi, pandemi döneminde hayatın durma noktasına geldiği süreçte çok basit ve anlaşılır bir reklam kampanyası yürütmüş ve logosu üzerinden sosyal mesafe uyarısı vermeyi hedeflemiştir. Bu durumda markanın her iki toplum için hazırladığı reklamda ülkeye göre uyarlanmış özel bir mesaj bulunmamaktadır. Gerek göstergeler gerekse dilsel aktarım açısından kaynak metin ve erek metin arasında örtüşme söz konusudur. Marka yerelleştirme yapmayı tercih etmemiş ve çok net bir strateji benimseyerek her iki topluma da ulaşmaya çalışmıştır. Reklamların maddi yükü ve pandemi döneminde birçok fabrikada üretimin durma noktasına gelmesi, hatta durması göz önünde bulundurulduğunda, firma maddi kaygı güderek, bu şekilde hareket etmiş ve verilmek istenilen mesaj en az maliyet ile hedef kitleye ulaştırılmış olabilir.

BMW, Almanya için kullandığı reklam filmini birçok kültüre birebir uyarlarken Türkiye için bu stratejiyi tercih etmemiştir. Çeviri stratejisi olarak ele aldığımızda ise Almanya'da gösterilen reklamdan çok farklı bir senaryo ve etiket ile karşılaşmaktayız. Türk pazarı için glokal reklam seçeneği ile yeni bir reklam oluşturulmuştur ve Almanya için hazırlanan reklamdan farklı olarak bireylere sosyal sorumluluk yüklemek yerine geleceğe dair umutları yeşertmeyi hedeflemiştir. Oldukça uzun ve duygusal bir reklam ile Türk müşterisine seslenen firma, özellikle haz, keyif, eğlence gibi özlemleri birer motif olarak kullanmıştır. Bu motifler tüketicilerin zihinlerinde BMW marka otomobil kullanırken hissettikleri ile özdeşleştirilmek amacı gütmüş olabilir.

Mercedes-Benz ise aynı göstergeler üzerinden oldukça yalın, net ve anlaşılır bir reklam stratejisi benimseyerek salt dilsel bir aktarım ile reklamı Türk pazarına uyarlamıştır. Kültür farkları ve her dilin kendi dinamiğini oluşturan etkenler dışında neredeyse birebir aynı strateji ile her iki pazara da seslenebilmiştir. Söz konusu sosyoekonomik koşullar düşünüldüğünde, bunun karşılığı olan bir çözüm olduğu söylenebilir. Bir taraftan üretimin durduğu, belirsizliklerle dolu bir süreçte kaynakların doğru ve yerine tüketilmesi aynı zamanda da bireyleri sorumluluk üstlenmeye çağırırken, hayatları pahasına sistemin devam etmesini sağlayan meslek gruplarına teşekkür ederek bir taraftan gönülleri kazanmaya ve böylece marka hakkında zihinlerde olumlu bir algı oluşturmaya çalışmıştır. Çevreci bir yaklaşımla, en az kaynak tüketimi ve aynı strateji ile birçok farklı pazarda etkili reklam örneği açısından firmanın taktiğinin başarılı olduğu yorumu yapılabilir. 
Volkswagen markasında, yine, glokal reklam örneği ile karşılaşmaktayız. Markanın Türkiye pazarı için hazırlamış olduğu reklam, Alman pazarı için hazırlanan reklamdan tamamen bağımsız bir yerelleştirme örneğidir. Firmanın Almanya ve dünyanın birçok bölgesi için aynı reklamın İngilizcesini uyarlaması söz konusuyken Türkiye için bu stratejiyi uygulamaması dikkat çekicidir. Oysa, oldukça basit ve yalın hazırlanmış reklam, dilsel bir aktarımla Türkçeye uyarlanabilirdi. Üstelik dönemin şartları gereği çok daha etkili ve akıllarda kalıcı olabilirdi. Ancak, Türk pazarı için yine gelecekteki umut dolu günlere atıf yaparak global reklam stratejisini uygulamamıştır. Markanın Türk tüketicisini kültürel çözümlene ile mantıktan ziyade, duyguları ile yakalamayı hedeflemiş olabilir. Türk tüketicinin kolektivizm özelliğinden yararlanarak bir duygusal bağ oluşturmayı amaçlamış olduğu söylenebilir.

Incelenen reklamlarda özellikle göstergeler üzerinden mesaj veren Mercedes-Benz markasının reklamı minimum maliyet ile maksimum etkinlikte bir strateji olarak dikkat çekmektedir. Bu reklamın Türkçeye uyarlanması yerinde bir yöntem olarak değerlendirilebilir. Özellikle yeni senaryolar ve görsellerle farklı söylemler üzerinden yürütülen kampanyalarda Türk tüketicisinin duyulara ve duygulara hitap etmesi açısından görsel olarak etkilemesi hedeflemiş olabilir ve bu bağlamda özellikle kolektivizm boyutu ile dikkat çeken Türk toplumunun bağ kurma, sahiplenme, sahip çıkma anlayışının etkili olduğu söylenebilir. Elde edilen bulgulardan yola çıkarak, reklamcılık sektöründe tüm dünyayı etkisi altına alan global sorunlara hem global hem glokal çözümler ile yaklaşmanın mümkün olduğu ifade edilebilir.

\section{Kaynakça}

Batı, U. (2013). Reklamın dili. İstanbul: Alfa Yayınları.

Cahen, A. (2003). Interkulturelle werbung, Münih: GRIN Verlag (https://www.grin.com/document/14600)

Gülsoy, T. (1999). Reklam terimleri ve kavramları sözlüğü. İstanbul: Adam Yayınları

Hofstede, G. (1993). Interikulturelle zusammenarbeit. Wiesbaden: Gabler Verlag.

Hofstede, G., Hofstede, G.J. \& Minkov, M. (2010). Cultures and organizations. McGraw-Hill eBooks. ISBN: 978-0-07-177015-6.

Hofstede, G., Hofstede, G. J., Mayer, P., Sondermann, M., Lee, A. (2011): Globales Denken, lokales Handeln. Interkulturelle Zusammenarbeit und globales Management. 6. Aufl. München: dtv.

Kloss, I. (2003). Werbung. Oldenburg: WiSo Lehr- und Handbücher

Levitt, T. (1983). The globalization of markets, Harvard Business Review, 61(3), 92-102.

Reiß, K. \& Vermeer, H. J. (2014). Towards a General Theory of Translational Action-Skopos Theory Explained. New York: Routledge.

Stolze, R. (2008). Übersetzungstheotien. Tübingen: Narr Francke Attempto Verlag.

Tekin, B. (2018). Hayatın anlamını semboller üzerinden okumak: Dünyanın boğulmuş en güzel adamı. Folklor/edebiyat, 24(95), 2018/3. DOI: 10.22559/folklor.293 